\title{
Comparison of Surgical Outcomes of Radical Prostatectomy Using the Multicenter Korean Prostate Cancer Registry (KPCR) Database
}

\author{
Sung Hye Yu' ${ }^{1}$, Mun Joo Choi ${ }^{1}$, Choung-Soo Kim² ${ }^{2}$ Seong II Seo ${ }^{3}$, Chang Wook Jeong ${ }^{4}$, Seok-Soo Byun ${ }^{5}$, Ji Youl Lee ${ }^{6}$, \\ Jun Hyuk Hong ${ }^{2}$, In Young Choi ${ }^{1}$ \\ 'Department of Medical Informatics, College of Medicine, The Catholic University of Korea, Seoul; ${ }^{2}$ Department of Urology, Asan Medical Center, \\ University of Ulsan College of Medicine, Seoul; ${ }^{3}$ Department of Urology, Samsung Medical Center, Sungkyunkwan University School of Medicine, Seoul; \\ ${ }^{4}$ Department of Urology, Seoul National University Hospital, Seoul National University College of Medicine, Seoul, ${ }^{5}$ Department of Urology, Seoul \\ National University Bundang Hospital, Seoul National University College of Medicine, Seongnam; ${ }^{6}$ Department of Urology, Seoul St. Mary's Hospital, \\ College of Medicine, The Catholic University of Korea, Seoul, Korea
}

Objectives: Prostate cancer, commonly is rapidly increasing the incidence of prostate cancer among Korean men. Primary treatment of localized prostate cancer involves radical prostatectomy, and surgery techniques are divided into the abdominal, laparoscopic, and robotic surgery. Different surgical techniques differ in quality of life, economic aspect, and outcome of surgery and prognosis. Therefore we compared the outcomes and prognosis of patients who underwent surgery for localized prostate cancer using the multicenter Korean Prostate Cancer Registry (KPCR) database. Methods: The KPCR database collected data of 6,032 patients from five medical institutions, and data standardization and quality management were performed to ensure data integrity. We extracted data necessary for analysis from the KPCR database. We analyzed data for 3,262 patients during the period from January 2006 to December 2011. The demographic characteristics, surgical outcomes, and prognosis of patients with localized prostate cancer were analyzed. All statistical analyses were performed using one-way ANOVA, chi-square test, and post-hoc analysis. We used the Kaplan-Meier method and multivariable Cox proportional hazard regression model for biochemical recurrence-free survival rate (BCR-FS) analysis. Results: The analysis results showed that the average initial prostate specific antigen value was $10.30 \mathrm{ng} / \mathrm{mL}$. A total of $56.7 \%$ of the patients had clinical stage T2, 43.3\% had stage T1, and $64.4 \%$ of the patients had a Gleason score of more than 7. The rate of positive surgical margin was radical retropubic prostatectomy, laparoscopic radical prostatectomy, robotic-assisted laparoscopic radical prostatectomy (RALP) as 33.6\%, 27\% and 28.8\%, respectively $(p<0.001)$. The RALP gave excellent results for postoperative complication, and estimated blood loss (EBL). The 5-year overall BCR-FS was $77.0 \%$, and the three surgical techniques did not differ in clinical outcomes. Cox regression analysis showed that the surgical technique did not affect the biochemical recurrence rate. Conclusions: Our study describes the characteristics of patients with localized prostate cancer and their prognosis. These results indicate that patients and medical staff can rely on information from the KPCR database for decision-making.

Key words: Prognosis, Prostatectomy, Prostatic neoplasms, Registries

\section{INTRODUCTION}

Prostate cancer is the second most common cancer in men worldwide, the most common among men in the United States, and the fifth most common among Korean men [1,2]. The incidence of prostate cancer in Korea has risen sharply from 10.9 per 100,000 population in 2003 to 38.6 per 100,000 population in 2014 [3]. This change is due to the increased life expectancy and improved accessibility of medical institu-

\author{
Corresponding author: In Young Choi \\ 222 Banpo-daero, Seocho-gu, Seoul 06591, Korea \\ Tel: +82-2-2258-7870, E-mail: iychoi@catholic.ac.kr \\ Co-corresponding author: Jun Hyuk Hong \\ 88 Olympic-ro 43-gil, Songpa-gu, Seoul 05505, Korea \\ Tel: +82-2-3010-3740, E-mail: jhhong@amc.seoul.kr \\ Received: June 11, 2018 Revised: July 11, 2018 Accepted: July 19, 2018 \\ *This work was supported by the National Research Foundation of Korea (NRF) grant funded by the \\ Korean Government (MSIP) (No. NRF, 2016R1A2B4015922).
}

How to cite this article:

Yu SH, Choi MJ, Kim CS, Seo SI, Jeong CW, Byun SS, Lee JY, Hong JH, Choi IY. Comparison of surgical outcomes of radical prostatectomy using the multicenter Korean Prostate Cancer Registry (KPCR) database. J Health Info Stat 2018;43(3):175-183. Doi: https://doi.org/10.21032/jhis.2018.43.3.175

(c) It is identical to the Creative Commons Attribution Non-Commercial License (http://creativecommons.org/licenses/by-nc/4.0) whichpermit sunrestricted non-commercial use, distribution, and reproduction in any medium, provided the original work is properly cited.

(c) 2018 Journal of Health Informatics and Statistics

No potential conflict of interest relevant to this article was reported. 
tions as well as early detection of prostate cancer with the widespread use of prostate specific-antigen (PSA) tests $[4,5]$.

Prostate cancer can be used to differentiate clinical stages before treatment, determine the treatment regimen, and predict recurrence. Tumor stage is determined on the basis of TNM classification of malignant tumors [6]. The treatment of localized prostate cancer includes active surveillance (AS), watchful waiting (WW), radical prostatectomy (RP), and radiation therapy (RT). The choice of treatment method is determined by considering the patient's clinical-pathological condition and life expectancy [6]. Radical prostatectomy (RP), widely used as a standard treatment for localized prostate cancer, was first introduced to perineal prostate resection (RPP). Afterward the surgical technique has evolved into an radical retropubic prostatectomy (RRP) that can be performed with pelvic lymph node dissection (PLND). And laparoscopic radical prostatectomy (LRP) and robotic-assisted laparoscopic radical prostatectomy (RALP) have been developed. Recently, RALP has become the most preferred method for minimally invasive procedures, and the number of cases using the traditional RPP method has decreased. However, RRP and LRP are still used [5,7]. These various surgical techniques differ in prognosis, quality of life, and health-care cost [8].

Thus, surgical outcomes and prognostic information on prostate cancer are very important in the choice of treatment modalities and predicting prognosis. This is based on the assumption that a representative registry in which several agencies participate is necessary, but little is known about the effects and results of a treatment course determined using national data [9]. The Cancer of the Prostate Strategic Urologic Research Endeavor (CaPSURE) database was developed in 1995, and by 2016 it was affiliated with 43 institutions. A total of 15,209 patients who received various treatments for prostate cancer in the United States were enrolled [10,11]. The Japan Study Group for Prostate Cancer (J-CaP) database was established in 2001 to study 17,872 Japanese patients who received hormone therapy during prostate cancer treatment [10]. The Korea Study Group of Prostate Cancer (K-CaP) database was developed in 2001 and has enrolled 4,000 Korean patients who have undergone radical prostatectomy and contains data collected from three medical institutions. The K-CaP database is composed of clinical and oncological data of patients with prostate cancer, and some studies have been carried out to analyze the prognosis and pathologic results [10]. The Korean multicenter registry systems, such as CaPSURE and J-CaP, can provide important information for the selection of an appropriate treatment method for prostate cancer and help to improve the clinical management of future patients with prostate cancer [9]. The most common variable for surgical outcome is the use of PSA values to determine recurrence $[12,13]$. Biochemical recurrence (BCR) is known to occur 5 years after initial treatment in about $15 \%$ of the patients and 10 years after initial treatment in 20 to $40 \%$ of the patients $[14,15]$. Thus, BCR has a significant effect on the course and prognosis of the disease, and the outcome of BCR is an important factor in determining treatment options [16]. According to a study by Magheli et al. [17] 3-year BCR results for the surgical techniques of RRP, LRP, and RALP were not statistically significant. In Kim et al. [18]. study, the 5-year BCR-free survival (BCRFS) rate after RP for localized prostate cancer was reported to be $73.2 \%$.

In our study, based on the electronic medical records (EMR) data, we created the multi-institutional integrated extended K-CaP database. The purpose of this study was to compare the characteristics, outcomes, and prognosis of different surgical techniques used for the treatment of patients with localized prostate cancer.

\section{METHODS}

\section{Database development}

The data used in this study were from the Korean Prostate Cancer Registry (KPCR) database, which was created by extending the K-CaP database. The KPCR database contains data of 6,032 patients with prostate cancer who underwent radical prostatectomy in 5 institutions from May 2003 to December 2014. For each institution, the EMR associated with prostate cancer requires a data structure to accommodate a variety of data systems. Therefore, the EMR data from each institution were reclassified and standardized using the Prostate Cancer Common Data Model (ProC-CDM) developed in this study (Table 1). The ProC-CDM consists of 14 items and 142 variables in the clinical data. The validation rule was developed to ensure the accuracy and quality of the data and to identify wrong data.

\section{Statistical analysis}

From the KPCR database, EMR of 3,262 patients who underwent radical prostatectomy for localized prostate cancer between January 2006 and December 2011 were extracted, and a data mart was constructed (Figure 1). Based on the exclusion criteria for the data mart generation, the study excluded a total of 2,770 patients, which are as follows: 
Table 1. Structure of the prostate cancer common data model (ProC-CDM)

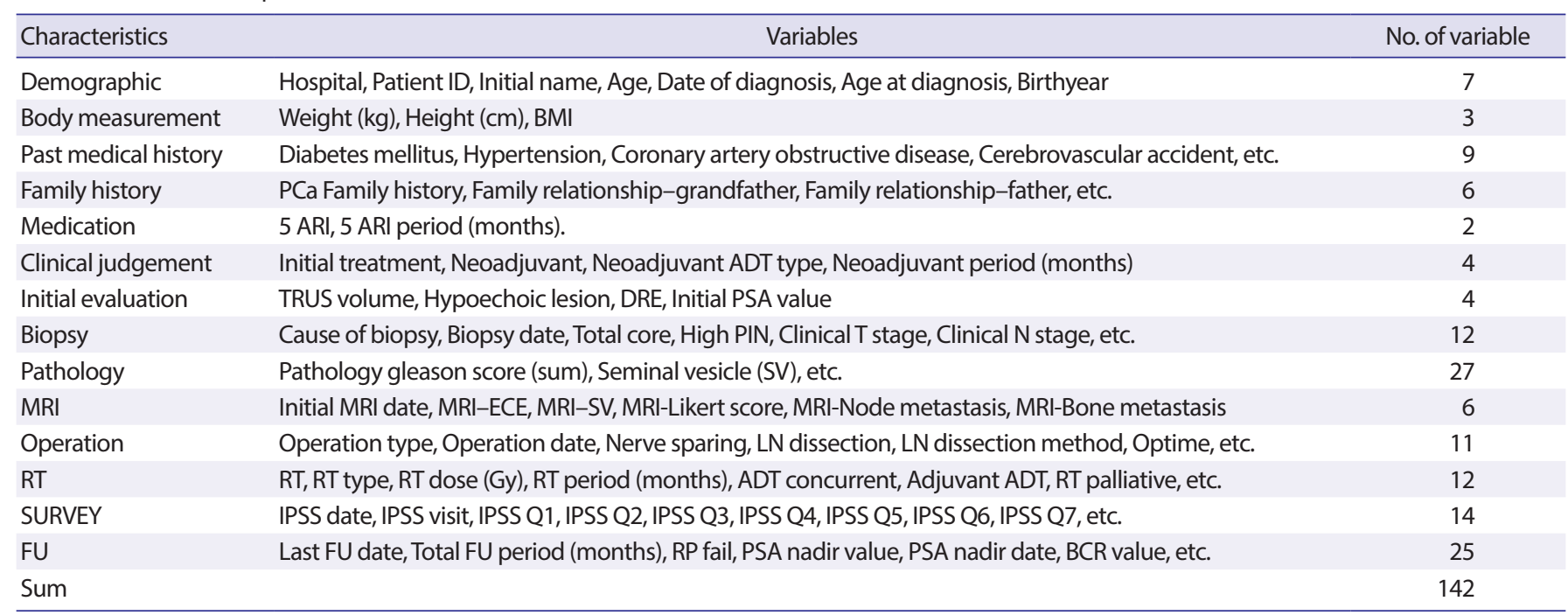

BMI, body mass index; 5 ARI, 5-alpha reductase inhibitor; ADT, androgen deprivation therapy; TRUS, transrectal ultrasonography; DRE, digital rectal examination; PIN, prostatic intraepithelial neoplasia; MRI, magnetic resonance imaging; ECE, extracapsular extension; LN, lympnode; RT, radiotherapy; IPSS, internationalprostatesymptomscore; PSA, prostate specific antigen.

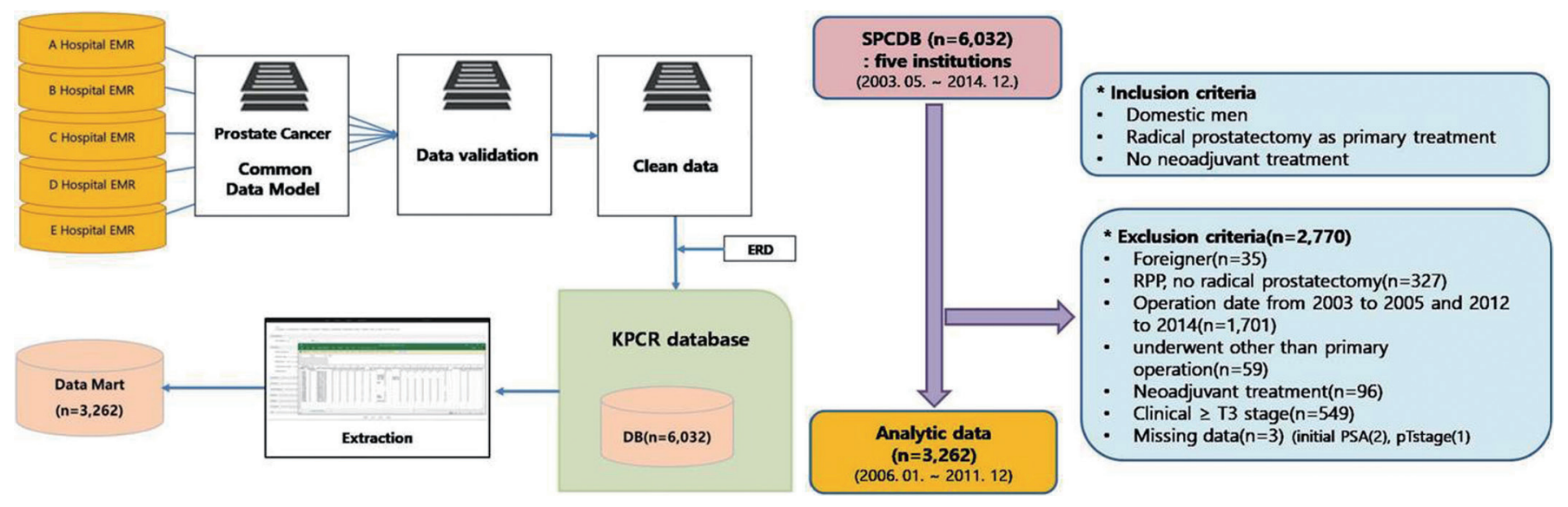

Figure 1. Development of a multicenter Korean Prostate Cancer Registry (KPCR) database.

327 patients with RPP surgery, other surgeries, and surgery days missing 1,701 patients with an operation date from 2003 to 2005 and 2012 to 2014, and 35 foreign patients. There were 59 patients who underwent other than primary operation treatment, 96 patients with neoadjuvant treatment, 549 patients with clinical T3, T4 stage, 2 patients with missing initial stage PSA, and 1 patients with missing pathologic T stage.

The chi-square test and one-way ANOVA were performed to analyze the clinical pathologic characteristics, and the post-hoc comparisons (Bonferroni correction method and Bonferroni test) was performed to compare the groups. The BCR-FS was calculated, and the differences were analyzed based on the surgical technique used and the pathologic
T stage. The Kaplan-Meier method was used to analyze the survival rate, and the difference in survival rate was confirmed by a log-rank test. And the multivariable Cox proportional hazard regression model analysis was performed to determine whether the surgical technique had an effect on survival. All statistical analyses were performed using SPSS version 18.0, and statistical significance was indicated by a $p$-value $<0.05$.

\section{Ethics statement}

The study protocol was approved by the institutional review board of at the Catholic University of Korea (IRB No. MC16RIMI0107). Informed consent was confirmed by the IRB. 


\section{RESULTS}

\section{Patients' characteristics}

Of the 3,262 patients, RRP was performed in 1,245 patients (38.2\%), LRP in 430 patients (13.2\%), and RALP in 1,587 patients (48.7\%). The mean age at diagnosis of the 3,262 patients was 65.7 years, and the mean body mass index (BMI) was $24.4 \mathrm{~kg} / \mathrm{m}^{2}$. A total of 506 patients (15.5\%) had diabetes mellitus, 1,402 patients (43.8\%) had hypertension, and 1,300 patients (39.9\%) had benign prostatic hyperplasia. The average initial PSA value was $10.30 \mathrm{ng} / \mathrm{mL}$. According to the clinical stage, 1,413 patients (43.3\%) had T1, 1,849 patients (56.7\%) had T2, and T2 was higher than T1. The mean follow-up period was 48.0 months. Pathological Gleason scores were $\leq 6,7$, and $\geq 8$ in 1,770 (23.6\%), 2,102 (64.4\%), and 361 (11.1\%) patients, respectively. The pathological stage was T0 in 16 pa- tients (0.5\%), T2 in 2,299 (70.5\%), T3 in 930 patients (28.5\%), and T4 in 17 patients $(0.5 \%)$, with the proportion of $\mathrm{T} 2$ patients being the highest (Table 2)

\section{Outcome according to surgical technique}

The mean rate of positive surgical margin was $30.4 \%$ and was lower in LRP than in RRP and RALP (RRP, 33.6\%; LRP, 27.0\%; RALP, 28.8\%). There was not a significant difference between surgical technique in surgical margins ( $p=0.112$ ). The mean operation time was 190.4 minutes and it was lower in RRP than in RALP and LRP. The mean length of hospital stay was 8.2 days and was shorter in LRP than in RRP and RALP. The mean EBL was $481.3 \mathrm{~mL}$ and was lower in RALP than in RRP and LRP. The complication rates determined using the Clavien-Dindo classification were $9.9 \%$ in the overall grade, $3.9 \%$ in the minor grade, and $6.5 \%$

Table 2. Patient characteristics

\begin{tabular}{|c|c|c|c|c|c|c|}
\hline \multirow{2}{*}{ Characteristics } & \multirow{2}{*}{$\frac{\text { RRP }}{\mathrm{n}(\%) \text { or Mean } \pm \mathrm{SD}}$} & \multirow{2}{*}{$\frac{\text { LRP }}{\mathrm{n}(\%) \text { or Mean } \pm \text { SD }}$} & \multirow{2}{*}{$\frac{\text { RALP }}{n(\%) \text { or Mean } \pm S D}$} & \multirow{2}{*}{$\frac{\text { Total }}{\mathrm{n}(\%) \text { or Mean } \pm \mathrm{SD}}$} & \multicolumn{2}{|c|}{ Statistics } \\
\hline & & & & & $x^{2}$ or $F$ & $p$-value \\
\hline No. of patients & $1,245(38.2)$ & $430(13.2)$ & $1,587(48.7)$ & $3,262(100.0)$ & & \\
\hline Mean $\pm S D$ & $66.14 \pm 0.18$ & $66.32 \pm 0.30$ & $65.21 \pm 0.18$ & $65.71 \pm 6.83$ & & \\
\hline $\operatorname{BMI}\left(\mathrm{kg} / \mathrm{m}^{2}\right)$ & & & & & $5.85^{*}$ & $0.003^{*}$ \\
\hline Mean \pm SD & $24.39 \pm 0.8$ & $24.01 \pm 0.14$ & $24.50 \pm 0.7$ & $24.40 \pm 2.65$ & & \\
\hline DM & $199(16.0)$ & $66(15.3)$ & $241(15.2)$ & $506(15.5)$ & 0.17 & 0.840 \\
\hline HTN & $562(45.1)$ & $191(44.4)$ & $675(42.5)$ & $1,428(43.8)$ & 1.005 & 0.366 \\
\hline $\mathrm{BPH}$ & $551(49.0)$ & $103(32.1)$ & $646(52.2)$ & $1,300(39.9)$ & $21.023^{*}$ & $<0.001^{*}$ \\
\hline Initial PSA (ng/mL) & & & & & $8.34^{*}$ & $<0.001^{*}$ \\
\hline Mean $\pm S D$ & $11.41 \pm 12.90$ & $9.05 \pm 8.06$ & $9.78 \pm 13.41$ & $10.30 \pm 12.65$ & & \\
\hline Mean \pm SD & $54.31 \pm 0.70$ & $47.30 \pm 1.47$ & $43.18 \pm 0.49$ & $47.98 \pm 23.81$ & & \\
\hline Pathology GS & & & & & 28.58 & $<0.001^{*}$ \\
\hline$\leq 6$ & $310(24.9)$ & $129(30.0)$ & $331(20.9)$ & $770(23.6)$ & & \\
\hline 7 & $761(61.1)$ & $249(57.9)$ & $1,092(68.8)$ & $2,102(64.4)$ & & \\
\hline$\geq 8$ & $159(12.8)$ & $46(10.7)$ & $156(9.8)$ & $361(11.1)$ & & \\
\hline Missing & $15(1.2)$ & $6(1.4)$ & $8(0.5)$ & $29(0.9)$ & & \\
\hline Pathology T stage & & & & & 3.93 & 0.686 \\
\hline рT0 & $7(0.6)$ & $4(0.9)$ & $5(0.3)$ & $16(0.5)$ & & \\
\hline pT2 & $872(70.0)$ & $295(68.6)$ & $1,132(71.3)$ & $2,299(70.5)$ & & \\
\hline pT3 & $359(28.8)$ & $129(30.0)$ & $442(27.9)$ & $930(28.5)$ & & \\
\hline
\end{tabular}

RRP, radical retropubic prostatectomy; LRP, laparoscopic radical prostatectomy; RALP, robotic-assisted laparoscopic radical prostatectomy; BMI, body mass index; DM, diabetes mellitus; HTN, hypertension; BPH, benign prostatic hyperplasia; PSA, prostate specific antigen; GS, gleason score. ; SD, standard deviation. ${ }^{*} p<0.01$. 
in the major grade. The complication rates of RRP in the overall, minor, and major grades were $12.9 \%$ (161 patients), 3.4\% (42 patients), and 9.9\% (123 patients), respectively. The complication rates of LRP in the overall, minor, and major grades were 20.2\% (87 patients), 12.3\% (53 patients), and $9.8 \%$ (42 patients), respectively. The complication rates of RALP in the overall, minor, and major grades were $4.7 \%$ (75 patients), 1.9\% (31 patients), and 3.0\% (47 patients), respectively. There was a significant difference between surgical technique in overall, major and minor complication $(p<0.001)$ (Table 3).

\section{The BCR-FS according to the surgical technique}

BCR-FS analysis was performed on a total of 3,262 patients. The 5-year BCR-FS was 76.3\%, 79.9\%, and 77.0\% for RRP, LRP, and RALP, respectively, and the overall rate was 77.0\%. The 5-year BCR-FS according to the pathological T2 stage was $82.8 \%, 87.6 \%$, and $85.9 \%$ for RRP, LRP and RALP, respectively. The 5-year BCR-FS according to the T3 stage was $61.8 \%, 64.0 \%$, and $54.1 \%$ for RRP, LRP, and RALP, respectively, and according to the T4 stage, it was $42.9 \%, 50 \%$, and $45 \%$ for RRP, LRP, and RALP, respectively. The significant difference between the 3 groups (RRP, LRP, and RALP) in pathological T2 and T3 stage was not signifi-

Table 3. Outcome according to surgical technique

\begin{tabular}{|c|c|c|c|c|c|c|c|}
\hline \multirow[b]{2}{*}{ Characteristics } & \multirow{2}{*}{$\begin{array}{c}\mathrm{RRP}^{\mathrm{a}} \\
\mathrm{n}(\%) \text { or } \\
\text { Mean } \pm \mathrm{SD}\end{array}$} & \multirow{2}{*}{$\begin{array}{c}\text { LRP }^{\mathrm{b}} \\
\mathrm{n}(\%) \text { or } \\
\text { Mean } \pm \mathrm{SD}\end{array}$} & \multirow{2}{*}{$\begin{array}{c}\text { RALP }^{c} \\
\mathrm{n}(\%) \text { or } \\
\text { Mean } \pm \text { SD }\end{array}$} & \multirow{2}{*}{$\begin{array}{c}\text { Total } \\
\mathrm{n}(\%) \text { or } \\
\text { Mean } \pm \text { SD }\end{array}$} & \multicolumn{3}{|c|}{ Statistics } \\
\hline & & & & & $\mathrm{X}^{2}$ or $\mathrm{F}$ & $p$-value & Post-hoc \\
\hline No. of patients & $1,245(38.2)$ & $430(13.2)$ & $1,587(48.7)$ & $3,262(100.0)$ & & & \\
\hline SM & $418(33.6)$ & $116(27.0)$ & $457(28.8)$ & $991(30.4)$ & 4.37 & 0.112 & \\
\hline \multicolumn{8}{|l|}{ Operation time (min) } \\
\hline Mean $\pm S D$ & $173.25 \pm 67.77$ & $253.46 \pm 59.19$ & $189.84 \pm 63.74$ & $190.43 \pm 69.39$ & $190.82^{*}$ & $<0.000^{*}$ & $\mathrm{~b}>\mathrm{c}>\mathrm{a}$ \\
\hline \multicolumn{8}{|l|}{ Length of stay (d) } \\
\hline Mean $\pm S D$ & $9.57 \pm 4.53$ & $5.31 \pm 2.42$ & $7.68 \pm 3.85$ & $8.19 \pm 4.25$ & $158.49^{*}$ & $<0.000^{*}$ & $a>c>b$ \\
\hline \multicolumn{8}{|l|}{$\mathrm{EBL}(\mathrm{cc})$} \\
\hline Mean \pm SD & $746.06 \pm 633.19$ & $465.26 \pm 277.69$ & $285.12 \pm 302.81$ & $481.30 \pm 497.82$ & $213.58^{*}$ & $<0.000^{*}$ & $a>b>c$ \\
\hline \multicolumn{8}{|l|}{ Complications by Clavien-Dindo classification } \\
\hline Perioperative (Overall) & $161(12.9)$ & $87(20.2)$ & $75(4.7)$ & $323(9.9)$ & $115.81^{* *}$ & $<0.000^{* *}$ & $a>b>c$ \\
\hline Minor perioperative (Grades I and II) & $42(3.4)$ & $53(12.3)$ & $31(1.9)$ & $126(3.9)$ & $251.87^{* *}$ & $<0.000^{* *}$ & $a>c>b$ \\
\hline Major perioperative (Grades III, IV, and V) & $123(9.9)$ & $42(9.8)$ & $47(3.0)$ & $212(6.5)$ & $559.03^{* * *}$ & $<0.000^{* *}$ & $b>a>c$ \\
\hline
\end{tabular}

RRP, radical retropubic prostatectomy; LRP, laparoscopic radical prostatectomy; RALP, robotic-assisted laparoscopic radical prostatectomy; SM, surgical margin; EBL, estimated blood loss; $\mathrm{SD}$, standard deviation.

${ }^{*} p<0.01, * *$ Significantat $p<0.0083$ level after adjusting for post-hoc comparisons (Bonferroni correction).
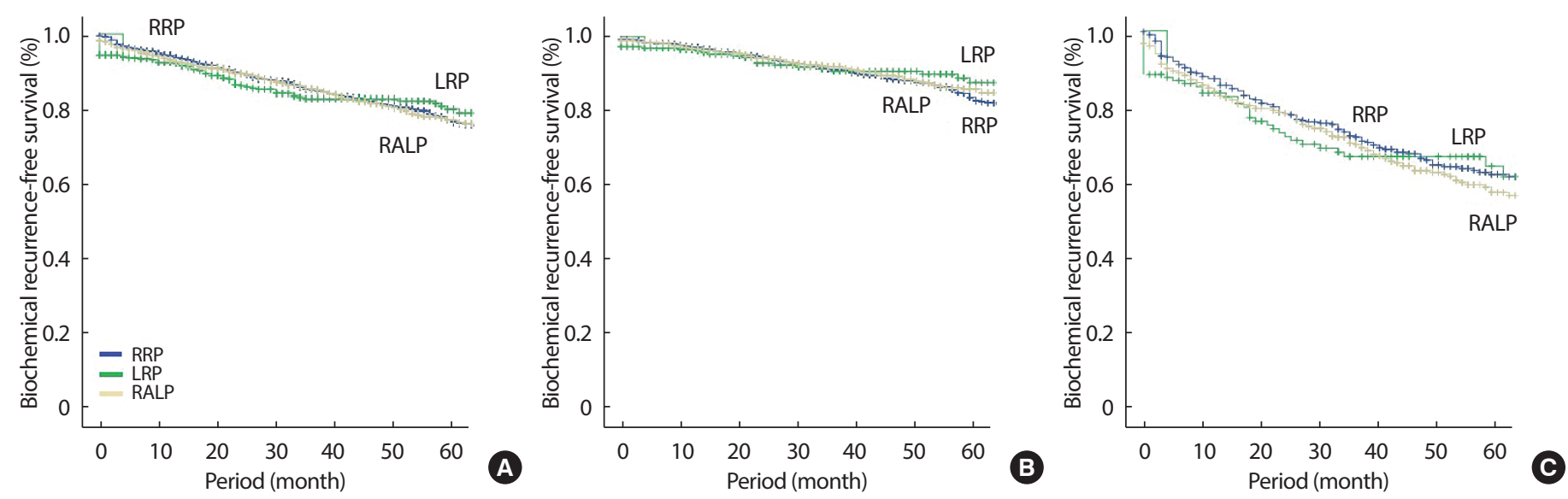

Figure 2. (A) Based on the surgical technique, the 5-year biochemical recurrence-free survival (BCR-FS) rate in patients who underwent radical retropubic prostatectomy (RRP), laparoscopic radical prostatectomy (LRP), and robot-assisted laparoscopic radical prostatectomy (RALP) was 76.3\%, 79.9\%, and $77.0 \%$, respectively. (B) For the pathological stage T2, the 5-year BCR-FS in patients who underwent RRP, LRP, and RALP was $82.8 \%, 87.6 \%$, and $85.9 \%$, respectively. (C) For the pathological stage T3, the 5-year BCR-FS in patients who underwent RRP, LRP, and RALP was 61.8\%, $64.0 \%$, and $54.1 \%$, respectively. 
Table 4. The 5-year biochemical recurrence-free survival rate according to surgical technique and pathological stage of the tumor

\begin{tabular}{lccccc}
\hline 5-year BCR-FS (\%) & RRP & LRP & RALP & Total & $p$-value \\
\hline Overall & 76.3 & 79.9 & 77.0 & 77.0 & 0.731 \\
Pathologic T2 stage & 82.8 & 87.6 & 85.9 & 84.5 & 0.490 \\
Pathologic T3 stage & 61.8 & 64.0 & 54.1 & 60.0 & 0.638 \\
Pathologic T4 stage & 42.9 & 50.0 & 45.0 & 35.7 & 0.385 \\
\hline
\end{tabular}

$\mathrm{BCR}-\mathrm{FS}$, biochemical recurrence-free survival; RRP, radical retropubic prostatectomy; LRP, laparoscopic radical prostatectomy; RALP, robotic-assisted laparoscopic radical prostatectomy.

cant: $p=0.490$ (T2) and $p=0.638$ (T3). The BCR-FS results are shown in Figure 2 and Table 4.

\section{Cox multivariable analysis showing surgical technique affects of biochemical recurrence}

There was no statistical significance in confirming whether the surgical technique affected the survival rate. Therefore, it was confirmed by multivariable Cox proportional hazard regression analysis, whether the surgical technique affects the biochemical recurrence rate. The results of the analysis showed that both the LRP and RALP methods did not affect the biochemical recurrence rate based on the RRP (RR for LRP and RRP: 0.856, 95\% CI =0.435-1.684, $p=0.652$; RR for RALP and RPR: $1.076,95 \% \mathrm{CI}=0.813-1.422, p=0.609)$. In the other variables, the pathologic Gleason score of 8 points or more influenced the biochemical recurrence rate by 6.861 times compared to the score of 6 points or less (RR for 7 and $\leq 6: 2.458,95 \% \mathrm{CI}=1.618-3.732, p<0.001$; $\mathrm{RR}$ for $\geq 8$ and $\leq 6: 6.861,95 \% \mathrm{CI}=4.274-11.014, p<0.001)$. The biochemical recurrence rate was statistically significant in the variables of pathology T4, T3, surgical margin, clinical T2, initial PSA, and EBL (Table 5).

\section{DISCUSSION}

The KPCR database is constructed using multi-institutional integrated data and provides information about the characteristics, pathologic results, and prognosis of localized prostate cancer. We obtained the following results. The overall rate of positive surgical margin was $30.4 \%$, and which was lower in the order of LRP, RALP and RRP. Kim et al. [4] reported a $33.8 \%$ rate of positive surgical margin for all surgical techniques, suggesting that the progress of surgical techniques has improved the outcome. Guillaume et al. [19] showed that LRP gave better results than RALP, which has a limit on the number of samples from a single
Table 5. Cox multivariable analysis showing predictors of biochemical recurrence

\begin{tabular}{|c|c|c|}
\hline Factors & $\mathrm{RR}(95 \% \mathrm{Cl})$ & $p$-value \\
\hline Age at diagnosis & $0.982(0.965-0.999)$ & 0.034 \\
\hline $\mathrm{BMI}\left(\mathrm{kg} / \mathrm{m}^{2}\right)$ & $1.016(0.973-1.060)$ & 0.471 \\
\hline \multicolumn{3}{|l|}{ DM } \\
\hline Negative* & 1.000 & - \\
\hline Positive & $1.216(0.913-1.620)$ & 0.181 \\
\hline \multicolumn{3}{|l|}{ HTN } \\
\hline Negative* $^{*}$ & 1.000 & - \\
\hline Positive & $1.071(0.859-1.336)$ & 0.540 \\
\hline \multicolumn{3}{|l|}{$\mathrm{BPH}$} \\
\hline Negative* & 1.000 & - \\
\hline Positive & $1.151(0.920-1.440)$ & 0.217 \\
\hline Initial PSA (ng/mL) & $1.009(1.005-1.014)$ & $<0.001$ \\
\hline \multicolumn{3}{|l|}{ Clinical T stage } \\
\hline $\mathrm{cT} 1^{*}$ & 1.000 & - \\
\hline cT2 & $1.360(1.083-1.707)$ & 0.008 \\
\hline Total follow-up period (mon) & $1.001(0.994-1.007)$ & 0.863 \\
\hline \multicolumn{3}{|l|}{ Pathology GS } \\
\hline$\leq 6^{*}$ & 1.000 & - \\
\hline 7 & $2.458(1.618-3.732)$ & $<0.001$ \\
\hline$\geq 8$ & $6.861(4.274-11.014)$ & $<0.001$ \\
\hline \multicolumn{3}{|l|}{ Pathology T stage } \\
\hline pT2* & 1.000 & - \\
\hline pT3 & 2.141 (1.644-2.787) & $<0.001$ \\
\hline pT4 & $2.266(1.128-4.550)$ & 0.021 \\
\hline \multicolumn{3}{|l|}{ Operation type } \\
\hline RRP* & 1.000 & - \\
\hline LRP & $0.856(0.435-1.684)$ & 0.652 \\
\hline RALP & $1.076(0.813-1.422)$ & 0.609 \\
\hline \multicolumn{3}{|l|}{ SM } \\
\hline Negative* & 1.000 & - \\
\hline Positive & $1.766(1.381-2.258)$ & $<0.001$ \\
\hline Operation time (min) & $1.001(0.999-1.003)$ & 0.363 \\
\hline Length of stay $(d)$ & $1.013(0.991-1.037)$ & 0.250 \\
\hline $\mathrm{EBL}(\mathrm{mL})$ & $1.000(0.999-1.000)$ & 0.008 \\
\hline \multicolumn{3}{|c|}{ Perioperative complications (Overall) } \\
\hline Negative* & 1.000 & - \\
\hline Positive & $0.816(0.192-3.459)$ & 0.782 \\
\hline \multicolumn{3}{|c|}{ Minor perioperative complications (Grades I and II) } \\
\hline Negative* & 1.000 & - \\
\hline Positive & $1.661(0.425-6.497)$ & 0.466 \\
\hline \multicolumn{3}{|c|}{ Major perioperative complications (Grades III, IV, and V) } \\
\hline Negative* & 1.000 & - \\
\hline Positive & $1.181(0.321-4.348)$ & 0.902 \\
\hline
\end{tabular}

BMI, body mass index; DM, diabetes mellitus; $\mathrm{HTN}$, hypertension; $\mathrm{BPH}$, benign prostatic hyperplasia; PSA, prostate specific antigen; GS, gleason score; RRP, radical retropubic prostatectomy; LRP, laparoscopic radical prostatectomy; RALP, robotic-assisted laparoscopic radical prostatectomy; $\mathrm{SM}$, surgical margin; $\mathrm{EBL}$, estimated blood loss; $\mathrm{RR}$, relative risk; $\mathrm{Cl}$, confidence interval.

*Reference group. 
institution (LRP, 26.6\%; RALP, 31.3\%). The results of the meta-analysis conducted by Ashutosh et al. [20] shows that RALP is superior to LRP and RRP (RALP, 16.2\%; LRP, 20.4\%; RRP, 24.2\%). The results of this study were similar to those of the study by Guillaume et al. [19] The rate of positive surgical margin, which is the factor for evaluating the surgical outcome, was found to be better in RALP and LRP than the RRP.

Postoperative complication rates were lower in RALP than RRP and LRP. In Ashutosh et al. [20] study, RALP had a lower complication rate than RRP and LRP, and Giovanni et al. [21] and Ryu et al. [22] also reported a lower complication rate in RALP than in RRP. In contrast, the results of Guillaume et al. [19] were not significantly different, but LRP showed better results than RALP. The results of this study also suggest that the complication rates of RALP are low and complications are gradually reduced due to the development of surgical techniques.

The 5-year BCR-FS was 76.3\%, 79.9\%, and 77.0\% for RRP, LRP, and RALP, respectively, and the overall rate was $77.0 \%$. This was much higher than the 5-year BCR-FS of 48\% observed in Kim et al. [4] study, but was similar to the 5-year BCR-FS of 73.2\% observed in Kim et al. [18] study. Studies conducted in other countries showed a higher the 5-year BCRFS than those in Korea; Misop et al. [21] study showed a rate of $84 \%$ and Mani et al. [22] study showed $86.6 \%$. In the present study, the results of BCR-FS according to the pathologic T stage were not significant differences. The BCR-FS in this study was similar that observed in the study by Kim et al. [4] and Kim et al. [18] (Kim et al. [4], BCR-FS of 61\% according to T2 and BCR-FS of 32\% according to T3; Kim et al. [18], 61.2\% of BCR-FS according to T2 and 40.4\% of BCR-FS according to T3). BCRFS and pathologic stage of this study were inversely proportional to each other. The risk of recurrence is higher in Korean patients with prostate cancer than in foreign patients with prostate cancer, suggesting that BCR-FS may have a negative impact on prognosis.

Our study had several limitations. First, the medical institutions registered in the KPCR database had local data limited to the provinces of Seoul and Kyonggi. Thus, selection bias could have occurred in the process of collecting patient data. However, Ko et al. [23] reported that 78\% of radical prostatectomies were performed in Seoul and Kyonggi in Korea. Therefore, we believe that the possibility of selection bias is low as our study population reflects the uniform distribution of surgical patients in Korea. Second, the experience and proficiency of the clinician with the operative technique may affect the prognosis, which is not accounted for in this study. Third, EMR data are used in conducting retro- spective studies. Since the EMR data provided by each medical institution do not have the same structure, a common data model was applied to extract the information common to the prostate cancer research, and it was possible to perform an integrated analysis of the standardized data in this multicenter study. Fourth, the LRP results showed that there were medical institutions in the KPCR database (which consisted of data obtained from about $66 \%$ of the registered medical institutions) that did not implement LRP. This could have caused a bias in the results, compared to other surgical techniques. Fifth, since the total follow-up period was as short as 48 months, long-term follow-up survival rate was needed.

However, to the best of our knowledge, our study is significant and is the first study to compare the three surgical techniques using the data from the KPCR database. The KPCR database could contribute to the progress of surgeries in Korea and improve the characteristics, outcomes, and prognosis of localized prostate cancer in the country.

\section{CONCLUSIONS}

There was no standard structure for the data present in the prostate cancer registries in Korea, which made it difficult to standardize, integrate, and verify the data. Our research shows the characteristics of localized prostate cancer and its prognosis. These results indicate that the patients and medical staff can rely on information from the KPCR database for decision-making. If we continue to integrate and periodically update the standardized data presented in our study, this database will lay the ground work for future long-term research.

\section{ORCID}

Sung Hye Yu http://orcid.org/0000-0001-9608-8868

Mun Joo Choi http://orcid.org/0000-0002-8415-6453

Choung Soo Kim https://orcid.org/0000-0002-7464-3207

Seong Il Seo https://orcid.org/0000-0002-9792-7798

Chang Wook Jeong https://orcid.org/0000-0002-2200-5019

Seok Soo Byun https://orcid.org/0000-0001-9356-9500

Ji Youl Lee http://orcid.org/0000-0001-6775-1157

Jun Hyuk Hong https://orcid.org/0000-0003-2705-0481

In Young Choi http://orcid.org/0000-0002-2860-9411 


\section{REFERENCES}

1. Torre LA, Siegel RL, Ward EM, Jemal A. Global cancer incidence and mortality rates and trends - an update. Cancer Epidemiol Biomarkers Prev 2016;25(1):16-27. DOI: 10.1158/1055-9965

2. Siegel RL, Miller KD, Jemal A. Cancer statistics, 2016. CA Cancer J Clin 2016;66(1):7-30. DOI: 10.3322/caac.21332

3. National Cancer Center. Annual report of cancer statistics in Korea in 2014. 2016, p. 26-27 (Korean).

4. Kim D, Byun S, Lee S, Lee E, Choi H, Chung B. The features and prognosis of korean who underwent radical prostatectomy in prostate cancer. Korean J Urol Oncol 2010;8:40-46 (Korean).

5. Coelho RF, Rocco B, Patel MB, Orvieto MA, Chauhan S, Ficarra V, et al. Retropubic, laparoscopic, and robot-assisted radical prostatectomy: a critical review of outcomes reported by high-volume centers. J Endourol 2010;24(12):2003-2015. DOI: 10.1089/end.2010.0295

6. National Comprehensive Cancer Network. Prostate cancer, Version 3. NCCN clinical practice guidelines in oncology. 2016, p. ST-1, MS-2MS-39.

7. Park JH, Lee SE, Choi YH, Song W, Choi HY. Twenty-year single surgeon experience with radical perineal prostatectomy: oncologic, functional outcomes and perioperative complications. Korean J Urol Oncol 2016;14(3):144-151 (Korean).

8. Porpiglia F, Morra I, Chiarissi ML, Manfredi M, Mele F, Grande S, et al. Randomised controlled trial comparing laparoscopic and robot-assisted radical prostatectomy. Eur Urol Oncol 2013;63(4):606-614. DOI: 10.1016/j.eururo.2012.07.007

9. Choi IY, Park S, Park B, Chung BH, Kim CS, Lee HM, et al. Development of prostate cancer research database with the clinical data warehouse technology for direct linkage with electronic medical record system. Prostate Int 2013;1(2):59-64 (Korean). DOI: 10.12954/PI. 12015

10. Lee DH, Lee SH, Rha KH, Choi IY, Lee JY, Kim SW, et al. The establishment of $\mathrm{K}-\mathrm{CaP}$ (the multicenter Korean prostate cancer database). Korean J Urol 2013;54(4):229-233 (Korean). DOI: 10.4111/kju.2013. 54.4 .229

11. Herlemann A, Cowan JE, Carroll PR, Cooperberg MR. Communitybased outcomes of open versus robot-assisted radical prostatectomy. Eur Urol Oncol 2018;73(2):215-223. DOI: 10.1016/j.eururo.2017.04. 027
12. Cookson MS, Aus G, Burnett AL, Canby-Hagino ED, D’Amico AV, Dmochowski RR, et al. Variation in the definition of biochemical recurrence in patients treated for localized prostate cancer: the American Urological Association Prostate Guidelines for Localized Prostate Cancer Update Panel report and recommendations for a standard in the reporting of surgical outcomes. J Urol 2007;177(2):540-545. DOI: 10.1016/j.juro.2006.10.097

13. The Korean Prostate Society. Prostate cancer treatment. Tutorial 2012, p. 35-37 (Korean).

14. The Korean Prostate Society. Prostate Cancer. Seoul: Ilchokak; 2017, p. 288-289 (Korean).

15. Pound CR, Partin AW, Eisenberger MA, Chan DW, Pearson JD, Walsh PC. Natural history of progression after PSA elevation following radical prostatectomy. JAMA 1999;281(17):1591-1597.

16. Lee JW, Cho KS, Han KS, Kim EK, Joung JY, Seo HK, et al. Epidermal growth factor receptor as predicting factor on biochemical recurrence after radical prostatectomy: a prospective study. Korean J Urol 2008; 49(11):974-980 (Korean).

17. Magheli A, Gonzalgo ML, Su LM, Guzzo TJ, Netto G, Humphreys $\mathrm{EB}$, et al. Impact of surgical technique (open vs laparoscopic vs robotic -assisted) on pathological and biochemical outcomes following radical prostatectomy: an analysis using propensity score matching. BJU Int 2011;107(12):1956-1962. DOI: 10.1111/j.1464-410X.2010.09795.x

18. Kim SC, Jeong I, Song C, Hong JH, Kim CS, Ahn H. Biochemical recurrence-free and cancer-specific survival after radical prostatectomy at a single institution. Korean J Urol 2010;51(12):836-842 (Korean). DOI: 10.4111/kju.2010.51.12.836

19. Ploussard G, de la Taille A, Moulin M, Vordos D, Hoznek A, Abbou CC, et al. Comparisons of the perioperative, functional, and oncologic outcomes after robot-assisted versus pure extraperitoneal laparoscopic radical prostatectomy. Eur Urol Oncol 2014;65(3):610-619. DOI: 10.1016/j.eururo.2012.11.049

20. Tewari A, Sooriakumaran P, Bloch DA, Seshadri-Kreaden U, Hebert AE, Wiklund P. Positive surgical margin and perioperative complication rates of primary surgical treatments for prostate cancer: a systematic review and meta-analysis comparing retropubic, laparoscopic, and robotic prostatectomy. Eur Urol Oncol 2012;62(1):1-15. DOI: 10.1016/ j.eururo.2012.02.029

21. Han M, Partin AW, Zahurak M, Piantadosi S, Epstein JI, Walsh PC. Biochemical (prostate specific antigen) recurrence probability follow- 
ing radical prostatectomy for clinically localized prostate cancer. J Urol 2003;169(2):517-523. DOI: 10.1097/01.ju.0000045749.90353.c7

22. Menon M, Bhandari M, Gupta N, Lane Z, Peabody JO, Rogers CG, et al. Biochemical recurrence following robot-assisted radical prostatec- tomy: analysis of 1384 patients with a median 5-year follow-up. Eur Urol Oncol 2010;58(6):838-846. DOI: 10.1016/j.eururo.2010.09.010 23. Goo WJ, Kim KH, Han JH, Kim DW, Ko EY. Analysis of urology robot surgery in Korea. 2014, p. 35-36 (Korean).

\section{국문초록}

\section{다기관 한국 전립샘 암 등록(KPCR) 데이터베이스를 이용한 근치적 전립샘 절제술의 수술 결과 비교 유성혜·최문주·김청수·서성일·정창욱·변석수·이지열·홍준혁·최인영}

목적: 전립샘암은 한국 남성에서 발병률이 급격히 증가하는 추세이다. 국소 전립샘암의 표준 치료로 근치적 전립샘 절제술이 시행되고 있으며 수술 기법은 개복, 복강경 그리고 로봇 수술로 나뉜다. 여러가지 수술 기법은 삶의 질, 경제적 측면, 수술 및 예후의 결과에서 차 이가 있다. 이에 저자는 다기관 한국 전립샘 암 등록(KPCR) 데이터베이스를 이용하여 국소 전립샘 암 수술을 시행한 환자들의 결과와 예후에 대한 결과를 비교하고자 한다.

방법: KPCR 데이터베이스에는 5 개 의료기관에서 수집한 6,032 명의 데이터가 수집되어 있고 데이터의 무결성 보장을 위해 데이터 표준 화 및 품질 관리를 시행하였다. KPCR 데이터베이스로부터 분석에 필요한 데이터를 추출하였다. 추출된 데이터는 2006 년 1월부터 2011 년 12월까지 수집된 3,262명으로 최종 분석을 시행하였다. 이 데이터를 이용하여 수술 기법에 따른 국소 전립샘 암 환자의 인구학적 특 성, 수술 결과 및 예후에 대해 분석하였다. 통계 분석방법은 one-way ANOVA, chi-square test, post-hoc 분석을 실시하였다. 무재발 생존 율 분석을 위해 Kaplan-Meier와 multivariable Cox proportional hazard regression model을 통해 분석을 실시하였다.

결과: 분석 결과, 초기 전립샘 특이 항원치의 평균 값은 $10.30 \mathrm{ng} / \mathrm{mL}$ 이었다. 총 환자의 $56.7 \%$ 는 임상 병기 T2를, $43.3 \%$ 는 병기 T1을 가지 고 있었고 환자의 64.4\%는 글리슨 스코어가 7 이상이었다. 절제면 양성률의 결과는 개복수술이 $33.6 \%$, 복강경 수술이 $27.0 \%$, 로봇수술 이 28.8\%로 나타났다 $(p<0.001)$. 로봇수술은 수술 후 합병증 및 예상 출혈량 결과에서 우수한 결과를 나타냈다. 5 년 생화학 무 재발 생 존율은 전체 환자에서 $77.0 \%$ 의 결과를 보였고 세 수술 기법은 임상 결과에 있어서 차이가 없었다. 또한 Cox 회귀분석 결과 세 수술기법 은 생존율에 영향을 미치지 않았다.

결론: 본 연구결과는 국소 전립샘 암 환자의 예후와 특성을 설명한다. KPCR 데이터베이스를 통한 본 결과는 환자와 의료진의 올바른 의사 결정에 도움을 줄 것이라는 것을 보여준다.

주제어: 예후, 근치적 전립샘 절제술, 전립샘 암, 레지스트리 